Tarik Duran

Faculty of Philology

University of Belgrade
UDC 811.163.41'373.2(497.11)

DOI https://doi.org/10.18485/fid.2017.7.ch14

\title{
HYBRID TOPONYMS OF VLACH - TURKISH TOPONYMASTIC COMPOSITION IN THE TIMOK REGION
}

У раду су сакупљени и анализирани хибридни топоними дволексемног састава од којих једна од лексема има влашку а друга турску структуру. Ономастичко-топономастичка грађа за ово истраживање ексцерпирана је из топографских карата Тимочке Крајине у издању Географског института. Морфолошком, семантичком и етимолошком анализом ових хибридних топонима изведени су закључци о утицају турског језика на влашки у домену топономастике у Тимочкој Крајини. У раду је дата основна класификација топонима и представљено је и објашњено десет познатих хибридних топонима ради њиховог представљања како научној тако и широј српској јавности.

Кључне речи: топоними, топономастика, ономастика, туркологија, турски топоними, влашки топоними, Тимочка Крајина.

\section{A short history and geography of the Timok Region}

The Timok region is a geographic region that encompasses the counties of Zajechar and Bor and it is located in the valley of the Timok river. This region is divided into seven municipalities and can be called mountainous, because it covers the territories of the mountains of Homolj, Stara Planina and Rtanj.

Similarly to the whole of the Balkan Peninsula, the Timok region has also been a place where many peoples came into contact. In addition to the peoples of the Old Balkans such as Illyrians, Thracians, Dacians and Celts many others such as Sarmatians, Alans, Goths, Germans, Scythians, Greeks, Huns, Avars, Slavs, Bulgars, Hungarians, Pechenegs, Cumans and certainly the Romans have passed through this region. All of these population groups have more or less influenced the language and cultural heritage of not only the Timok region, but the whole Balkan Peninsula. Apart from the aforementioned peoples, for whose sojourn we can find evidence 
documented in historical and geographical writings, the influence of the Turks on the Serbian and the Vlach people was extended significantly after the battle of Marica (26.10.1371) and the battle of Kosovo (28.06.1389). After these two battles, the seriously weakened aborigines of these regions found themselves in a difficult position. Thus, the Hungarians in order to take advantage of this situation, made a push to the South. Therefore, the Serbs and the Vlachs found themselves surrounded by both the Turks and the Hungarians (Đorović 2004: 263-279). The Vlachs, shifting from the Turks' side to that of the Hungarians and vice versa, played a major role in imprinting the history of the Balkans and the Ottoman Empire.

\section{The Vlachs}

There are many theories about the Vlach people, their origin and the origin of their ethnonym Vlach. The most commonly accepted is that of by professor Zef Mirdit who says that the name Vlach, is the ethnic name for Arumunje, Meglenorumunje and Istrorumunje but not for Dakorumunje. So the Meglenorumunji instead of the ethnonym Romanus used the name Vlaş, singular Vla, Vlau, to refer to themselves and from this ethnonym the following adjectives were derived vlaşés, -vlaşeásca ,rumunjski“. This was the name that the Germans initially used to refer to their south and west Celtic neighbours, but its use later changed to refer only to the inhabitants of the Italic peninsula- Walscher. Over time the ethnonym Walchos started to refer to the Roma, the French and the Italians, the people who spoke one of the Romance languages (Mirdita 2009:25-26).

From historic, especially Roman sources, we can draw some objective conclusions about the Vlachs. As Slavoljub Gacović has pointed out the Vlachs and the genesis and origin of their language has been introduced to the public by the the work of Kekaumenosa, Ansbertusa, Gervayiusa de Tilburza, Ioana de Sultanyeha, Rinaldadegli Albiyia, Flavia Bionda, Nicolausa Machinensisa, Antona Bonfinia, Francesca della Vallea, Jana Laskia, Giovanandrea Grome, Gáspara Héltaia. Kekaumenos was the first to mention the Vlach people on the shore of the rivers Sava and Danube at the end of XI century (1075-78), Gervayisa de Tilbuza mentioned "the land of the Vlachs" (terra Blacti) which he claimed to be placed "between 
the settlement of Ravno and the place of Niš" (vicus Ravana et vicus Nifa) in the XII century, more precisely in the year of 1211. Ioan de Sultanyeh in his work Notitia Orbis mentioned the land "Vulgaria or Bulgaria" (Vulgaria sive Bulgaria), the citizens of which speak a "language similar to Latin" (habent linguam propriam et quasi latinam) or that "the Vulgars spoke vulgar Roman language" (Ideo vocantur Vulgari a lingua Vulgarica romana)“"(Gacović 2014:197).

The etnonym Vlah appears in Turkish sources as Ulah or Ulahlar and the toponym Eflak is used for the land of Vlachia. Based on this toponym we can conclude that the name for the land of Vlachia entered Turkish languages as Vlahia. Due to the fact that two consonants never occur together at the beginning of Turkish words, this loanword has been adapted to the Turkish phonetic system by the insertion of an epenthetic vowel before the initial cluster, that is by adding the phoneme $\mathbf{e}$ at the beginning of the word and replacing the phonemes $\mathbf{v}$ and $\mathbf{h}$ with $\mathbf{f}$ and $\mathbf{k}$ respectively. In this way, the Turkish name "Eflak" was formed. For this reason, "the old name for the village Vlahovo which belongs to the Svrljig municipality is Efljakova". (Gacović 2014:122). Even though in the modern Turkish language the name Ulah is the only term denoting the Vlach population, exonyms such as Karavlah and Karagun, denoting Vlachs in Greece and Sinsari (Cincari) denoting the population of Vlachs who inhabited Macedonia were used broadly in the past.

\section{Toponomastic of the Timok Region}

Toponomastics or toponomy is a relatively young scientific discipline that refers to the study of the names of cities, mountains, rivers and such. Toponomastics, which began to develop as a branch of onomastics, attracted the attention of not only onomatologists and linguists but of common people as well. Owing to its connection with sciences such as history, geography, ethnology or anthropology, toponomastics, as a science, has developed rather quickly.

Unfortunately, there are not enough toponomastic pieces of research which, among other things, study semantic analyses of toponyms that bear the mark of Turkish rule in these regions and depict the ethnic image of 
Turkish settlement in specific parts of this region. Serbia, as well as the whole of the Balkan Peninsula, is characterized by a rich and colorful toponomastic canvas for historic, ethnic and cultural reasons. Therefore, from a scientific point of view it is crucial to study the toponyms of Turkish origin in Serbian regions.

In his work, from the late XVII century, the famous Turkish writer Evlija Čelebija (1611-1682) during his travel from Vidin to Belgrade mentioned only Zaječar and Kursundža which is today's Knjaževac. "After I had departed /from Vidin/it took eight hours of journeying to reach a konak in Aztur village. Ibrahim-pasha was camping with his military on the field called Sama čayiri and when I met him and kissed his hand, he told me... We crossed the river Timok which springs from the Timok Mountains and merges with Danube close to the cities of Vidin and Kladovo on horses. We continued for the next five hours before reaching the city of Kuršundžu. We moved forward from there and reached Banja" (Čelebija 1996:349).

From this late XVII century work we can conclude that except for the city of Zaječar, Knjaževac, Soko Banja and others on the shores of Danube, there were not many populated places. Geographical characteristics certainly have a big influence on the toponomastic portrait of a certain region. In this research we gathered a lot of hybrid oronyms which shows that the region in question is a mountainous one.

\section{Hybrid toponyms}

Toponyms can be formed from personal names and surnames, that is patronyms or from the names of plants, animals, nationalities and such. Apart from this, when it comes to the structure, toponyms can be simple or complex. Naturally, hybrid toponyms are complex because they are formed from two or more words or they are formed by adding toponomastic suffixes. Hybrid toponyms are names of places which are derived from words i.e. components from different languages. The toponyms which are formed from two words where one word belongs to Turkish and the other to Vlach language fall under the first classification. And the toponyms which are formed when a suffix is added to a word stem fall under the second classification. In this piece of work all toponyms belong to the first classification, meaning they are all formed from lexemes which have Vlach and Turkish structure. 
As it is commonly presumed, the largest number of toponyms in Serbia is of Serbo-Turkish origin. However, there are also those which are of Turkish-Hungarian and or Turkish-Vlach origin. This also refers to the Timok Region where Turkish-Serbian and Serbian-Turkish toponyms prevail. Some of these toponyms are: Majdanpek, Deligrad, Deli-Jovan, Šišmanovac.

Although the study of microtoponyms requires field research, for the purpose of this study we researched hybrid toponyms which can be found in topographic maps which are usually used for scientific or military purposes with a scale of 1:25000. Hence, the following hybrid toponyms have been registered:

- Čoka Begluki (hill - region),

- Čoka Kazak (hill - region),

- Kraku Đuluk (hill - region),

- Kraku Alat (hill),

- Kraku Mustafa (hill),

- Kraku Taušan(hill - region),

- Kraku Tokali (hill - region),

- Kraku Topal (hill),

- Opešu Kazan (river),

- Vlaška Mala (a quarter of Zaječar).

By means of narrow classification of these hybrid toponyms, it was determined that apart from Opesu Kazan (this toponym is a hidronym) and Vlaska mala (an area in the city of Zaječar) all other toponyms represent the names of mountains or hills i.e. they are all oronyms. After analyzing hybrid toponyms, it was determined that the first components of tponomastic syntagm were Vlach words kraku, čoka and the ethnonym Vlach. Components kraku and čoka refer to mountains and hills and are widespread toponyms across the Timok Region.

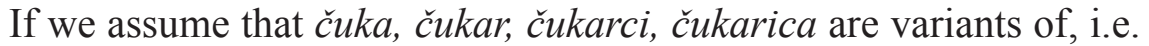
synonyms for "čoka" we can construct a theory which states that these words are derived from the Turkish words "çukur" meaning abyss or hole. However, in terms of semantics this theory is not acceptable. Nevertheless, it is important to consider the fact that the meaning of loanwords 
often changes during the transition from one language into another. Furthermore, the words čoka, čuka, čukar, čukarci, čukarica, čućer, čutaci may also originate from the Turkish word "kütük", "ćutuk" in Serbian and "chiutuc" in Romanian, meaning stamp or log (Gacović 2014:177). On the other hand, due to the fact that we can find examples of microtoponyms such as "čoka" and "čuka" as well as oykonym, a town of Čoka, near Senta in Vojvodina the question of whether these toponyms have a Hungarian origin emerges. Therefore, we believe that it is necessary to conduct multidisciplinary, field and comparative research in order to finally uncover the etymology of this word. If we take into consideration the poor geographical and climate conditions as well as historical facts, then we shouldn't be seeking etimological explanations of these toponyms in some old Balkan languages but rather reach conclusions within the languages of the people living in these areas in the recent past. We can claim with certainty that the word čoka which is found as an oronym in the Vlach Region represents the dialectical form of the Romanian word čuka meaning hill or mountain top. (Gacović 2014:187).

Coka Begluki: found in the municipality of Bor refers to a mountain and a region. This oronnym is formed from the words čoka and begluk (begluk $<$ beglik $<$ beylik). The word begluk (beylik), denoting beg-the Turkish title or a state property, was derived from the word beg (landlord, noble title, commander), that is from the old form bey and a suffix -luk(-llk, -lik, -lük) which denotes a place. (Radić 2001:68).

Čoka Kazak: found in the municipality of Bor refers to a mountain and a region. This hybrid toponym was derived from the ethnonym "Kazak". Mali Čerkez and Veliki Čerkez hills represent another example of hybrid toponyms of Turkish and Serbian origin found in the Timok Region. Across Serbia, there are many toponyms derived from ethnonyms such as: Čerkeska mala (quarter of Prokuplje city), Karaman (mountain), Kumanovci (village), Pečenjevce (village), Tatarija (village). Due to the fact that each of these ethnonyms can both be a nickname and a surname, it is possible that the toponyms are derived from either a nickname or a surname. However, it doesn't change the fact that they are most certainly ethnonimical.

Kraku Đuluk: This oronym is found between Žagubica and Majdanpek and refers to a hill and a small region. It consists of the determinators 
kraku and đuluk (güllük) meaning rosary ( a place where roses are cultivated or where they grow). A hybrid toponym was derived from a phytonim which was completely phonetically adapted to the Serbian language.

Kraku Alat: this hybrid toponym is found in the municipality of Bor. This oronym consists of the words kraku (hill) and alat (tool). Due to the fact that in Romania, which is on the other side of the river Danube, and mostly in Romanian Dobrudža there are seventy toponyms of Turkish origin (Enver 1979:152), it is not unusual that this oronym has been derived from the word alat which is also a Turkish loanword in the Serbian language.

Kraku Mustafa: this oronymis found near the city of Majdanpek consists of the words kraku (hill) and a patronym i.e. proper name Mustafa. Among all toponyms, the most numerous are the ones derived from personal names. However, uncovering the person after whom this hill was named would require a detailed investigation of historical sources.

Kraku Taušan: this oronym is found in the municipality of Bor and consists of the words kraku (hill) and zoonym taušan (rabbit). Zoonym taušan< rabbit is highly frequent as it also appears in Serbian surnames such as Taušan and Taušanovic (Duran 2008:31). This zoonym is also found in toponyms such as Taušanova česma in Macedonia (Polenakovnik 2007:181).

Kraku Tokali: found in the municipality of Bor refers to a hill and a small region. It consist of the words kraku (hill) and tokali (tokall) which denotes a person wearing toke, meaning armor (Skaljić 1989:619).

Kraku Topal: this oronym is found in the municipality of Bor and consists of the words kraku (hill) and topal (limping). This Turkish loanword is also a Balkanism and for this reason we find it as antroponyms and toponyms in all Balkan languages.

Opešu Kazan: contrary to the others, this hybrid toponym is a hydronym and it is found in the municipality of Bor. It is hard to determine the etymology and provide an explanation for the name of this river because the Vlach component "opešu" in this word is probably derived from the Serbian verb to bake. Conducting more detailed research might help determine the etymology of the verb to bake and its use as a loanword in the Vlach language in the Timok Region.

Vlaška Mala: this urbanonym is found in the city of Zaječar and represents the name for one part of the city of Zaječar. Besides the fact that 
it is an urbanonym, Vlaška Mala is at the same time an ethnonym and a hybrid toponym of the Turkish, the Serbian and the Vlach language. The word mala i.e. mahala (mahale) refers to the small part of the city and it is widespread throughout the whole of the Balkans.

Historically, the Timok Region, which belonged to the Eyalet of Vidin, was a very significant region not only for Turkish history but for Serbian as well. Its ethnic composition and topography makes it even more interesting. Therefore, for the purposes of onomastic research of the Timok Region we used topographic maps from the Institute of Geography and some toponomastic pieces of work. Naturally, our aim has been to draw conclusions about the influence of the Turkish language on the Vlach language in the Timok Region by conducting analyses of hybrid toponyms.

It is interesting that we were not able to find records of a single hybrid toponym in the municipality of Negotin. Nevertheless, there is a high probability that Vlach toponyms and maybe even hybrid toponyms of Turkish and Vlach origin can be found outside the Timok Region inhabited by Vlach populations. For this reason, there are 1638 Turkish loanwords in non-Roman languages (Polenakovnik 2007:74-194). When it comes to toponomastics, the Turkish language also had a huge influence on the Vlach language. In this piece of work, we have attempted to gather and analyze hybrid toponyms in the Timok Region which have a Turco-Vlach form and thus make our contribution to the field of toponomastics.

Sources:

Topographic maps:

1. Topographic map 1:25 000, Bor 1

2. Topographic map 1:25000, Bor 2

3. Topographic map 1:25000, Bor 3

4. Topographic map 1:25000, Bor 4

5. Topographic map 1:25 000, Bor 5

6. Topographic map 1:25000, Bor 6

7. Topographic map 1:25 000, Bor 7

8. Topographic map 1:25000, Bor 8

9. Topographic map 1:25000, Bor 9

10. Topographic map 1:25000, Bor 10

11. Topographic map 1:25 000, Bor 11 
12. Topographic map 1:25 000, Bor 12

13. Topographic map 1:25 000, Bor 13

14. Topographic map 1:25 000, Bor 14

15. Topographic map 1:25 000, Bor 15

16. Topographic map 1:25 000, Bor 16

17. Topographic map 1:25 000, Žagubica 1

18. Topographic map 1:25 000, Žagubica 2

19. Topographic map 1:25 000, Žagubica 3

20. Topographic map 1:25 000, Žagubica 4

21. Topographic map 1:25 000, Žagubica 5

22. Topographic map 1:25 000, Žagubica 6

23. Topographic map 1:25 000, Žagubica 7

24. Topographic map 1:25 000, Žagubica 8

25. Topographic map 1:25 000, Žagubica 9

26. Topographic map 1:25 000, Žagubica 10

27. Topographic map 1:25 000, Žagubica 11

28. Topographic map 1:25 000, Žagubica 12

29. Topographic map 1:25 000, Žagubica 13

30. Topographic map 1:25 000, Žagubica 14

31. Topographic map 1:25 000, Žagubica 15

32. Topographic map 1:25 000, Žagubica 16

33. Topographic map 1:25 000, Zaječar 1

34. Topographic map 1:25 000, Zaječar 2

35. Topographic map 1:25 000, Zaječar 3

36. Topographic map 1:25 000, Zaječar 4

37. Topographic map 1:25 000, Zaječar 5

38. Topographic map 1:25 000, Zaječar 6

39. Topographic map 1:25 000, Zaječar 7

40. Topographic map 1:25 000, Zaječar 8

41. Topographic map 1:25 000, Zaječar 9

42. Topographic map 1:25 000, Zaječar 10

43. Topographic map 1:25 000, Zaječar 11

44. Topographic map 1:25 000, Zaječar 12

45. Topographic map 1:25 000, Zaječar 13

46. Topographic map 1:25 000, Zaječar 14

47. Topographic map 1:25 000, Zaječar 15 
48. Topographic map 1:25 000, Zaječar 16

49. Topographic map 1:25 000, Negotin 1

50. Topographic map 1:25000, Negotin 2

51. Topographic map 1:25 000, Negotin 3

52. Topographic map 1:25000, Negotin 4

53. Topographic map 1:25000, Negotin 5

54. Topographic map 1:25000, Negotin 6

55. Topographic map 1:25 000, Negotin 7

56. Topographic map 1:25 000, Negotin 8

57. Topographic map 1:25000, Negotin 9

58. Topographic map 1:25 000, Negotin 10

59. Topographic map 1:25 000, Negotin 11

60. Topographic map 1:25 000, Negotin 12

61. Topographic map 1:25 000, Negotin 13

62. Topographic map 1:25 000, Negotin 14

63. Topographic map 1:25 000, Negotin 15

64. Topographic map 1:25 000, Negotin 16

\section{References:}

Bojanić, Dušanka. Fragmenti opširnog popisa Vidinskog sandžaka iz 1478-81. Beograd: Istorijski institut, 1973.

Bojanić, Dušanka. Turski zakoni i zakonski propisi iz XV i XVI veka za Smederevsku, Kruševačku i Vidinsku oblast. Beograd: Istorijski institut, 1974.

Bojanić-Lukač, Dušanka. Negotinska Krajina u vreme turske vladavine na osnovu izvora iz XV i XVI veka. Beograd: Glasnik Etnografskog muzeja 38, 1969.

Bojanić-Lukač, Dušanka. Zaječar $i$ Crna reka u vreme turske vladavine (XV-XVIII vek). Beograd: Glasnik Etnografskog muzeja 42, 1978.

Čelebija, Evlija. Putopis, odlomci ojugoslovenskim zemljama. Sarajevo: 1957.

Dimić, Dušan. Onomastika Sredske Župe. Leposavić: Institut za srpsku kulturu, 2003.

Duran,Tarik. Prezimena turskog porekla u Srbiji. Beograd, 2008./Neobjavljena magistarska teza/

Đinđić, Slavoljub, Teodosijević, Mirjana., Tanasković, Darko. Türkçe-Sırpça Sözlük. Ankara: Türk Dil Kurumu, 1997. 
Đorović, Vladimir. Istorija Srba. Niš: Zograf, 2004.

Enver, Mahmut. „Romen Toponimisindeki Türk Asılı Unsurların Bünyesi.“ S. Buluç. Milletlerarası Türkoloji Kongresi. Istanbul, 1979.

Gacović, Slavoljub. Neslovenske osnove u ojkonimima Vidinskog sandžaka XV i XVI veka. Zaječar: Matična biblioteka „Svetozar Marković“, 2014.

Gacović, Slavoljub. Od Rimljana i latinskog do Rumuna Timočana i rumunskog. Zaječar: Matična biblioteka „Svetozar Markovićc“, 2014.

Gacović, Slavoljub. Prilog toponomastičkoj etimologiji na tlu Timočke Krajine. Zaječar: Razvitak, 1985.

Jireček, Konstantin. Istorija Srba. Beograd, 1923.

Jireček, Konstantin. Zbornik Konstantina Jirečeka. Beograd: Naučno delo, 1959.

Loma, Aleksandar. Jezička prošlost jugoistočne Srbije u svetlu toponomastike. Niš, 1994.

Mirdita, Zef. VLASI starobalkasni narod. Zagreb: Hrvatski institut za povjest, 2009.

Mirković, Miroslava. Rimski gradovi na Dunavu u Gornjoj Meziji. Beograd, 1968.

Paunović, Bratislav-Bata. Vlasi kroz vekove. Ćuprija: Mladost, 2001.

Radenković, Radolsav. O etimologiji nekoh toponima jugoistočne Srbije. Zaječar: Razvitak, 1979.

Radić, Prvoslav. Turski sufiksi u srpskom jeziku. Beograd: Institut za srpski jezik SANU, 2001.

Rumunsko-srpskohrvatski rječnik. Pančevo. 1969.

Sakaoğlu, Saim. Türk Ad Bilimi. Ankara: Türk Dil Kurumu, 2001.

Skok, Petar. Prilozi proučavanju turcizama u srp-hrv. jeziku. Prage, 1938. Stojanović, Vojislav. Etnogeneza nastanka Vlaha. Zaječar: Kairos, 2007.

Škaljić, Abdulah. Turcizmi u srpskohrvatskom jeziku. Sarajevo, 1989.

Vojvodić, Stanko. Toponimi slovenskog porekla u Rumuniji. Kikinda, 2005. Vujaklija, Milan. Leksikon stranih reči i izraza. Beograd: 1980.

Zirojević, Olga. Srednji vek i period turske vladavine. Bor: Bor i okolina, 1973.

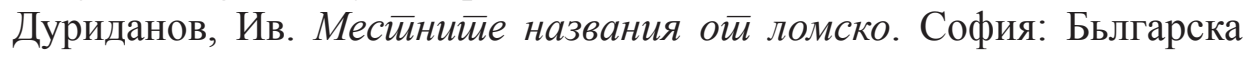
академия на науките, 1952.

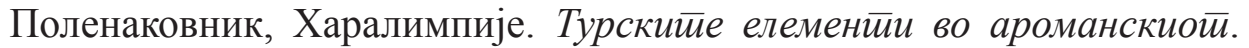
Скопје: Македонска академија на науките и уметностите, 2007. 


\begin{abstract}
In this paper we collected and analyzed hybrid toponyms combined of two lexemes of which one has a Vlach and the other a Turkish structure. Onomastic-toponymastic material for this study was excerpted from topographic maps of the Timok Region published by the Geographical Institute. Morphological, semantic and etymological analysis of these hybrid toponyms depict the influence of the Turkish language on the Vlach language in the domain of toponymastics in the Timok Region. The paper presents the basic classification of toponyms and discusses and analyzes ten famous hybrid toponyms for the purposes of their presentation to the scientific and broader Serbian public.
\end{abstract}

Keywords: toponyms, toponymastics, onomastics, turkology, Turkish toponyms, Vlach toponyms, Timok Region.

\title{
Biographical statement
}

TARIK DURAN was born on February 23rd in 1983 in Vize (Kirklareli/Turkey). He received primary education in Edirne (Republic of Turkey) and in 2001 graduated from Kepirtepe high school in the city of Luleburgaz. After completing his BA studies of Turkish Language and Literature at the University of Balikesir Necatibey Faculty in 2005, he came to Belgrade as a postgraduate student and a scholar of the Institute for International Scientific, Educational, Cultural and Technical Cooperation. Upon the completion of a one year Serbian language course at the Faculty of Philology in Belgrade, he enrolled for postgraduate studies - The Science of Language Course (Turkish language and literature) at the same faculty. In 2006/2007 academic year, he started working as a lector of the Department for Oriental studies. He obtained a Master's degree on June 6th 2009, after having defended his master thesis on the topic of "Surnames of Turkish origin in Serbia" (mentor: prof. dr Mirjana Teodosijević). In 2009/2010 academic year he started his PhD studies in the University of Belgrade, Faculty of Philology. He passed all of the required exams. Narrow field of his scholarly interest includes onomastics, etymology and dialectology. As a student of doctoral studies he has published several scientific papers such as: Etymology of Surnames Derived from Turkish Names of Occupation, Religious and Military Names (Језик и Друштво), International Confer- 
ence Philological Research Today (Филолошка истраживања данас), from 26th to 27th of November 2010, in Belgrade.) Turkish (Oriental) elements in Branislav Nusic's stories Night of Ramadan "International Conference on Turkish Language and Literature (UTEK), from 17th to 19th of May 2001, in Sarayevo) and Oronyms of Turkish origin in Montenegro (Second International Symposium on Language Education and Teaching from 26th to 28th of May in 2016 in Belgrade.)

E-mail: trkdrntr@hotmail.com 